\title{
EXPOSURE ASSESSMENT OF GROUNDWATER TRANSPORT OF TRITIUM FROM THE CENTRAL NEVADA TEST AREA
}

\author{
Prepared by \\ Karl Pohlmann, Jenny Chapman, and Roko Andricevic
}

Submitted to

Nevada Operations Office

U.S. Department of Energy

April 1995

DISCLAIMER

This report was prepared as an account of work sponsored by an agency of the United States Government. Neither the United States Government nor any agency thereof, nor any of their employees, makes any warranty, express or implied, or assumes any legal liability or responsibility for the accuracy, completeness, or usefulness of any information, apparatus, product, or process disclosed, or represents that its use would not infringe privately owned rights. Reference herein to any specific commercial product, process, or service by trade name, trademark, manufacturer, or otherwise does not necessarily constitute or imply its endorsement, recommendation, or favoring by the United States Government or any agency thereof. The views and opinions of authors expressed herein do not necessarily state or reflect those of the United States Government or any agency thereof.

\section{Publication \#45133}




\section{DISCLAIMER}

Portions of this document may be illegible in electronic image products. Images are produced from the best available original document. 
This report was prepared as an account of work sponsored by the United States Government. Neither the United States nor the United States Department of Energy, nor any of their employees, makes any warranty, express or implied, or assumes any legal liability or responsibility for the accuracy, completeness or usefulness of any information, apparatus, product or process disclosed, or represents that its use would not infringe privately owned rights. Reference herein to any specific commercial product, process, or service by trade name, mark, manufacturer, or otherwise, does not necessarily constitute or imply its endorsement, recommendation, or favoring by the United States Government or any agency thereof. The views and opinions of authors expressed herein do not necessarily state or reflect those of the United States Government or any agency thereof.

This report has been reproduced directly from the best available copy.

Available to DOE and DOE contractors from the Office of Scientific and Technical Information, P.O. Box 62, Oak Ridge, TN 37831; prices available from (615) 576-8401.

Available to the public from the National Technical Information Service, U.S. Department of Commerce, 5285 Port Royal Rd., Springfield, VA 22161. 


\title{
EXPOSURE ASSESSMENT OF GROUNDWATER TRANSPORT OF TRITIUM FROM THE CENTRAL NEVADA TEST AREA
}

\author{
prepared by \\ Karl Pohlmann, Jenny Chapman, and Roko Andricevic \\ Water Resources Center \\ Desert Research Institute \\ University and Community College System of Nevada
}

Publication No. 45133

submitted to

Nevada Operations Office

U.S. Department of Energy

Las Vegas, Nevada

April 1995

The work upon which this report is based was supported by the U.S. Department of Energy under Contract \#DE-AC08-95NV11508. 


\section{CONTENTS}

FIGURES $\ldots \ldots \ldots \ldots \ldots \ldots \ldots \ldots \ldots \ldots \ldots \ldots \ldots \ldots \ldots \ldots \ldots \ldots \ldots \ldots \ldots \ldots$

TABLE $\ldots \ldots \ldots \ldots \ldots \ldots \ldots \ldots \ldots \ldots \ldots \ldots \ldots \ldots \ldots \ldots \ldots \ldots \ldots \ldots \ldots \ldots \ldots \ldots$

INTRODUCTION $\ldots \ldots \ldots \ldots \ldots \ldots \ldots \ldots \ldots \ldots \ldots \ldots \ldots \ldots \ldots \ldots \ldots \ldots$

METHODOLOGY $\ldots \ldots \ldots \ldots \ldots \ldots \ldots \ldots \ldots \ldots \ldots \ldots \ldots \ldots \ldots \ldots \ldots \ldots \ldots$

Calculation of the Expected Tritium Concentration Profile $\ldots \ldots \ldots \ldots \ldots \ldots \ldots \ldots 2$

Calculation of the Human Health Risk $\ldots \ldots \ldots \ldots \ldots \ldots \ldots \ldots \ldots \ldots$

HYDROGEOLOGIC SETTING $\ldots \ldots \ldots \ldots \ldots \ldots \ldots \ldots \ldots \ldots \ldots \ldots \ldots \ldots$

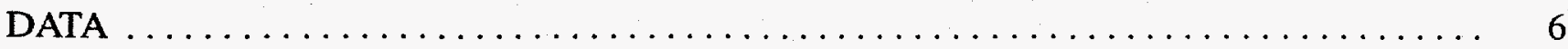

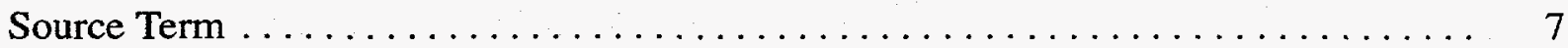

Discharge Mixing Area $\ldots \ldots \ldots \ldots \ldots \ldots \ldots \ldots \ldots \ldots \ldots \ldots \ldots \ldots \ldots$

Distance to Control Plane $\ldots \ldots \ldots \ldots \ldots \ldots \ldots \ldots \ldots \ldots \ldots \ldots \ldots \ldots \ldots$

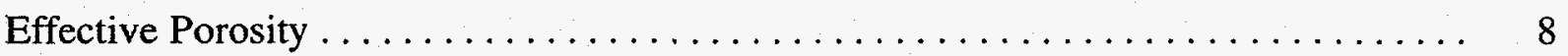

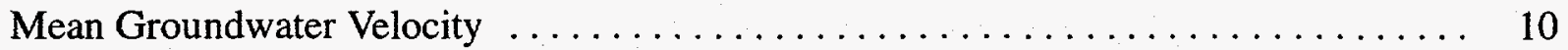

Spatial Variability in Hydraulic Conductivity $\ldots \ldots \ldots \ldots \ldots \ldots \ldots \ldots \ldots \ldots \ldots \ldots$

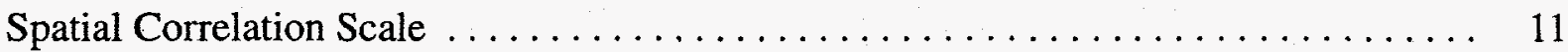

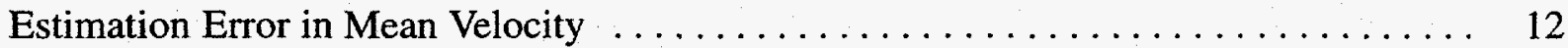

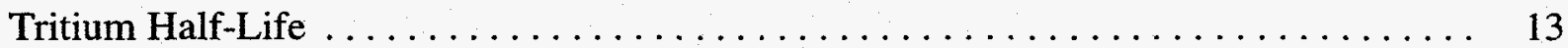

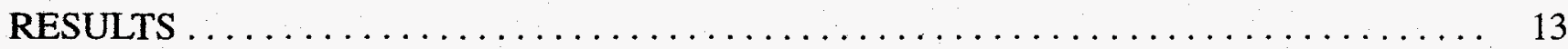

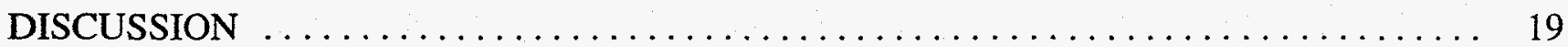

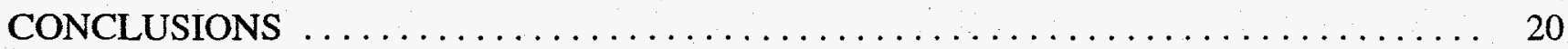

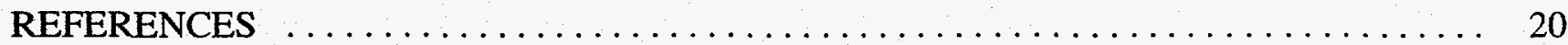




\section{FIGURES}

1. Location of the Faultless underground nuclear test site in Hot Creek Valley, Nevada. ... 5

2. Diagram of the two transport scenarios considered, showing the scenario number used in the report and the transport distance used in the calculations. $\ldots \ldots \ldots \ldots \ldots .9$

3. Correlation scales of hydraulic conductivity or transmissivity versus overall scale, as presented by Gelhar (1993) . . . . . . . . . . . . . . . . . . . . . . . . . . 12

4. Tritium breakthrough curves and corresponding standard deviations for Scenario 1 (4a) and Scenario $2(4 \mathrm{~b})$.

5. Sensitivity of tritium breakthrough to the value for spatial variability in $\ln K(5 a)$ and uncertainty in the mean velocity estimate (5b) for Scenario $1 \ldots \ldots \ldots \ldots \ldots, 16$

6. Sensitivity of tritium breakthrough to the value for spatial variability in $\ln K(6 \mathrm{a})$ and uncertainty in the mean velocity estimate (6b) for Scenario 2.

7. Probability distribution function for the excess-cancer-mortality risk calculated for Scenario 1 when the spatial variability, $\sigma^{2} \operatorname{lnK}$, is 0.6 , and there is no uncertainty assumed in the mean velocity estimate (Scenario 1a on Table 1).

\section{TABLE}

1. Health Risk Results for the Groundwater Transport Scenarios Considered at the Faultless Site. 


\section{INTRODUCTION}

The U.S. Department of Energy (DOE) and its predecessor agencies are responsible for nuclear weapons research and development as part of the national defense program. These activities include underground nuclear testing, and a small number of such tests have been conducted at sites distant from the Nevada Test Site (NTS). An NTS site-wide Environmental Impact Statement (EIS) is being prepared in 1995 and includes the two offsite test areas in Nevada: the Shoal site and the Central Nevada Test Area (CNTA). At the time of these tests, evaluations of project safety and predictions of groundwater transport of contaminants were made, and the tests were deemed safe to the public (U.S. Atomic Energy Commission, 1973, p. 2-5). These early evaluations were considered insufficient for the EIS, so DOE decided to perform a new exposure assessment for the Central Nevada Test Area. A separate evaluation of the Shoal site was also performed and is reported in Chapman et al. (1995).

The Central Nevada Test Area is in south-central Nevada in Hot Creek Valley. The area is in a remote desert region bordered on the southeast by U.S. Highway 6, approximately $100 \mathrm{~km}$ northeast of Tonopah and $180 \mathrm{~km}$ southwest of Ely. The only nuclear test conducted at the CNTA was Project Faultless on January 19, 1968. The purpose of the test was to determine the behavior of seismic waves generated by a nuclear detonation in Hot Creek Valley and to evaluate the potential usefulness of the site for high-yield experiments that could not be carried out at the NTS because of ground motion in Las Vegas. The device had a yield of less than one megaton and was detonated $975 \mathrm{~m}$ below land surface (Holmes and Narver, 1974).

The basic scenario evaluated for this exposure assessment is transport of tritium from the Faultless underground nuclear test by groundwater to a receptor well where an individual drinks the contaminated water for 70 years, centered around the time of peak tritium concentration. Two specific scenarios are analyzed. The first scenario presumes that a well is drilled at the boundary of the current DOE land withdrawal and is then used for drinking water supply. No supply wells currently exist at this location and thus the resultant risk does not apply to any current populations; however, there are no controls to prevent such a well from being drilled in the future. The second scenario considers transport to the first existing well along the downgradient flowpath.

This assessment strives to be as accurate as possible, but the lack of data requires that significant assumptions be made about some critical parameters. Measured values were used whenever possible, but given the lack of data, calculations were performed for ranges of certain parameters. The assessment can be made more realistic with the acquisition of additional site data.

\section{METHODOLOGY}

The three-dimensional reality through which a contaminant migrates in the subsurface environment is complicated by geologic heterogeneity and tortuous connected flowpaths. In the face of incomplete data and insufficient resources, the three-dimensional reality has to be simplified and conceptualized for a particular exposure assessment. The U.S. Environmental Protection Agency (EPA) has recently promulgated a new set of exposure-assessment guidelines to replace the previous (1986) 
version (U.S. EPA, 1992). The guidelines explicitly consider the need to estimate the distribution of exposures and discuss the need to incorporate uncertainty analysis into exposure assessment, which is also consistent with the most recent National Research Council (NRC) recommendations on exposure assessment (NRC, 1994). The EPA guidelines do not recommend specific models, but suggest that models match the objectives of the particular exposure assessment being conducted.

The technical and scheduling requirements of the EIS and scarcity of site data were inconsistent with a comprehensive exposure assessment, employing three-dimensional fate and transport modeling with characterization of geologic heterogeneity and spatial variability. Instead, a screening tool approach outlined in Daniels et al. (1993), Andricevic et al. (1994), and Andricevic and Cvetkovic (1995) was used. The employed modeling approach follows the EPA guidelines and incorporates real physical phenomena, such as instantaneous and/or slow release from the source, advection, dispersion, sorption, mass transfer, and possible uncertainty in the model parameters. The output is the expected concentration profile as a function of time (e.g., concentration breakthrough curves) at the compliance point downgradient from the source as well as the uncertainty around the expected concentration resulting from the natural geologic heterogeneity in general and from the spatially variable groundwater velocity in particular. The total exposure and corresponding uncertainty within the selected time interval (e.g., 70-year lifetime) is readily obtained from the model output and when multiplied with estimated intake and risk factors provides an estimate for individual human health risk presented by drinking groundwater downgradient from the source. The method can be considered in two distinct steps, described below: calculation of the expected tritium concentration profile and its standard deviation, and calculation of the health risk and its standard deviation.

\section{Calculation of the Expected Tritium Concentration Profile}

The solute flux method is described in detail by Andricevic and Cvetkovic (1995), while important elements of the approach can also be found in Daniels et al. (1993) and Andricevic et al. (1994). The following summary is derived from these sources, but the reader is directed to these references for a detailed treatment of the method.

The contaminant migration process is described in the solute flux method through the Lagrangian concept of motion following a particle on the pore scale. In the absence of direct information on groundwater velocities near Faultless, the mean velocity, $\bar{U}$, is calculated using the Darcy equation:

$$
\bar{U}=\frac{\overline{K J}}{\bar{n}}
$$

where $\bar{K}$ is the mean hydraulic conductivity, $\bar{J}$ is the mean hydraulic gradient, and $\bar{n}$ is the mean effective porosity. Hydrogeologic parameters such as $K$ and $n$ can be highly variable as a result of geologic heterogeneity. Numerous studies of the spatial variability of hydraulic conductivity have concluded that it is generally log-normally distributed (Freeze and Cherry, 1979; Hoeksema and Kitanidis, 1985). Thus, the natural logs of hydraulic conductivity data can be described by a normal distribution with a mean $\mu_{\ln K}$ and variance $\sigma^{2} \ln K$. The variance represents the variability of $K$ in 
space and may range from near zero for homogeneous deposits to five, or higher, for extremely variable porous media (Hoeksema and Kitanidis, 1985). Because it is distributed in space, $K$ usually has some degree of spatial correlation. The negative exponential function is often used to describe the $K$ correlation structure because it is found to correspond to $\ln K$ data and is easy to use (Hoeksema and Kitanidis, 1985). The correlation length of $K, \lambda$, represents the distance at which correlation between data points ceases. The higher the value of $\lambda$, the greater the spatial continuity of $K$. When the log-normal distribution and the negative exponential covariance function are assumed, the heterogeneous, isotropic hydraulic conductivity field can be statistically characterized by three parameters: $\mu_{\ln K}, \sigma^{2} \ln K$, and $\lambda$.

If the parameters on the righthand side of the Darcy equation are log-normally distributed, then so is $\bar{U}$ and the estimate of the mean velocity is $\mu_{\ln U}=\mu_{\ln K}+\mu_{\ln J}-\mu_{\ln n}$. The variance of the estimated mean $U, \sigma^{2} \ln U$, can be calculated as the sum of the variances of the other parameters, if sufficient data are available. $\sigma^{2} \ln U$ is referred to here as the estimation error in $U$ and represents the magnitude of uncertainty in the estimate of $U$ contributed by the estimation errors of $K, J$, and $n$. The magnitude of the uncertainty in the mean velocity, $\sigma^{2} \ln U$, will depend on the number of measurements used to estimate the parameters in the Darcy equation. In the case of independent measurements, $\sigma^{2} \ln U=$ $\sigma^{2} \ln U / N$, where $\sigma^{2} \ln U$ is the variance in the velocity field and $N$ is the number of measurements. For spatially correlated measurements, $\sigma^{2} \ln U$ is scaled by $N^{-1}[1+\bar{\varrho}(N-1)]$, where $\bar{\varrho}$ is an averaged spatial correlation between data points.

The solute flux method evaluates movement of a solute from the source to a plane perpendicular to the direction of flow. Aquifer heterogeneity is included and represented by the variance of $\log$-hydraulic conductivity, $\sigma^{2} \ln K$, and the hydraulic conductivity integral scale, $\lambda$. The combination of the spatial variability of aquifer properties and the uncertainty in the estimates of these properties causes the solute flux to be a random function described by a probability density function (pdf). The mean and variance of the solute flux are converted to the flux-averaged concentration needed for the risk calculations by dividing by the groundwater flux, $Q$. The first two moments of the flux averaged concentration are important in determining the total risk level. The larger the magnitude of variance in the flux-averaged concentrations, the larger the maximum potential risk.

\section{Calculation of the Human Health Risk}

Details of the human health risk calculations can be found in Daniels et al. (1993) and are summarized in Andricevic et al. (1994). The following summary is derived from those sources and the reader is referred to Daniels et al. (1993) for a detailed treatment of the method.

Once the groundwater transport of tritium has been calculated, the potential excess-cancer risk for an individual consuming the contaminated groundwater can be calculated. It is assumed that groundwater at one of the two compliance points considered here is the only source of drinking water for an individual. This would require drilling a new well for one of the scenarios. Exposure of the individual is assumed to begin at birth and continue without interruption over a 70-year lifespan (ICRP, 1990). This 70-year period is centered around the time of maximum annual tritium activity. 
The individual's committed effective dose is calculated by summing over the exposure period the products of the annual estimate of the activity (concentration) of tritium in the water as determined by the model, in units of $\mathrm{pCi} / \mathrm{l}$, the age-related annual intake of tap water, and the age-specific dose-conversion factor for each year of a 70-year lifespan.

Water intake is based on age-specific tapwater intake for both sexes and broad age categories for the western region of the U.S., quantified by Ershow and Cantor (1989). The rate of tapwater intake is assumed to be a lognormally distributed variable and the characteristics of the distribution have been described by Daniels et al. (1993). Exposure by other pathways (e.g., absorption through the skin while bathing) is not considered, and should not contribute substantially to the internal dose.

The individual's lifetime estimate of internal radiation dose is based on the dosimetric formalisms described in the International Commission on Radiological Protection (ICRP) Publication 60 (ICRP, 1991). A dose-conversion factor is used to calculate the lifetime dose from the individual's intake of tritium. To calculate the age-dependent committed effective dose per unit intake of radioactivity, each organ-specific committed equivalent dose in a given age category appearing in ICRP 56 was multiplied by its respective revised tissue-weighting factor from ICRP 60 and the products for that age category were summed. The age-category specific committed effective doses were considered to apply to each year of life identified for that age category. These annual age-specific committed effective doses are the dose-conversion factors used for estimating the lifetime dose for tritium in groundwater and agree with those calculated by Jain et al. (1992) using an analogous procedure. A tabulated summary of the factors used can be found in Daniels et al. (1993). A distribution for dose was calculated in a manner similar to that described by Daniels et al. (1993) using the distributions for activity, intake, and dose-conversion factors.

ICRP Publication 60 (ICRP, 1991), using data from numerous studies including the BEIR V report (NRC, 1990), computed a nominal risk value of $5 \times 10^{-2}$ per Sievert of lifetime committed effective dose for the probability of induced fatal cancer in a population of all ages following chronic low-dose exposure. This value was used by Daniels et al. (1993), and is used here. Additionally, this value is considered to be the geometric mean value of a lognormally distributed variable with the characteristics of this distribution as described by Daniels et al. (1993). The geometric mean of the maximum potential excess lifetime risk of cancer mortality is computed as the product of the geometric mean of the total committed effective dose and the geometric mean of the risk factor. The method for deriving the geometric standard deviation for this distribution is described by Daniels et al. (1993). This procedure is used to derive the 90 percent confidence intervals reported here for the individual excess cancer risk.

\section{HYDROGEOLOGIC SETTING}

The Faultless underground nuclear test was the only test conducted at the Central Nevada Test Area in Hot Creek Valley, between Tonopah and Ely. The hydrogeology of Hot Creek Valley is controlled in part by the basin-and-range topography (Figure 1). The valley is a long graben containing a sequence of Quaternary and Tertiary alluvial fill (up to $1200 \mathrm{~m}$ ) underlain by Tertiary volcanic rocks. The bounding ranges on either side of the valley contain Paleozoic carbonates 


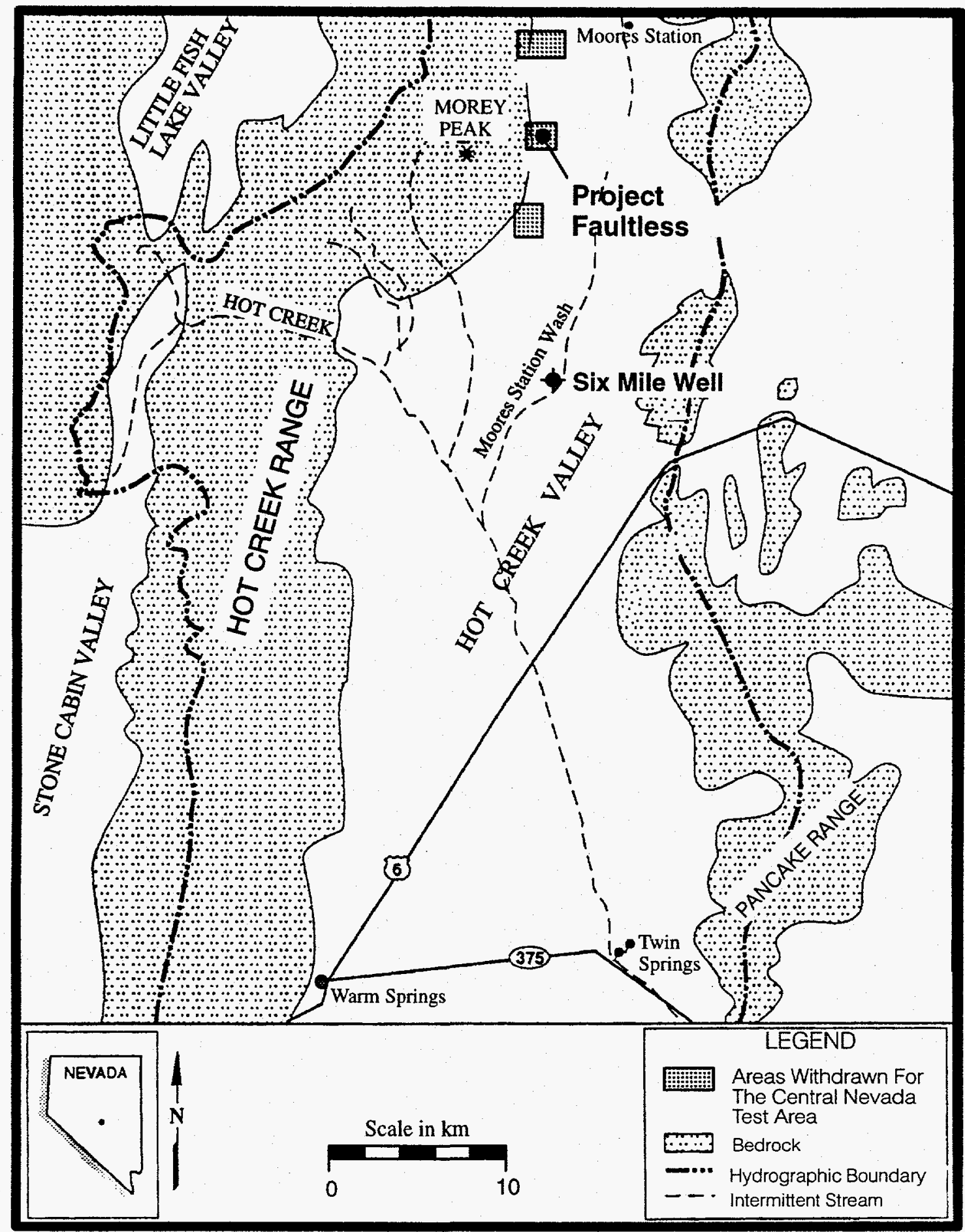

Figure 1. Location of the Faultless underground nuclear test site in Hot Creek Valley, Nevada. Six Mile Well is the closest existing location of downgradient water use. 
overlain by Tertiary-age volcanics (Thordarson, 1987). Boreholes close to the site generally penetrate approximately $610 \mathrm{~m}$ of alluvium underlain by tuffaceous sediments and volcanic rocks.

The water table in Hot Creek Valley generally occurs within the alluvium. Groundwater in the alluvium is believed to follow the general direction of surface flow (Rush and Everett, 1966; Fiero, 1968 ) with recharge in the mountain range to the west (Hot Creek Range). and groundwater flow toward the east-central part of the valley. Discharge is by evaporation in low portions of the valley (the area around Twin Springs Ranch), with a minor amount of subsurface flow out of Hot Creek Valley to Railroad Valley (Rush and Everett, 1966). Little information is available on water flow in the bedrock aquifers of the valley. Differences in hydraulic head, water chemistry, and temperature suggest that the alluvium and volcanics are distinct water-bearing zones (Dinwiddie and Schroder, 1971). Head values in the upper $340 \mathrm{~m}$ of section indicate that groundwater movement is generally south to southeastward. Head values measured in units 1500 to $2100 \mathrm{~m}$ below land surface reveal that the deep component of the flow system moves northeastward and eastward to Railroad Valley. Evaluation of vertical head gradients indicates a potential for downward flow in the north end of the valley, while an upward potential for flow exists over the southern part of the valley. The immediate test area is in a region of predominantly lateral flow toward the axis of the valley, between these recharge and discharge areas. Dinwiddie and Schroder (1971) concluded that vertical movement is slow relative to lateral flow, based on the anisotropy of hydraulic properties.

The Faultless detonation occurred in the tuffaceous sediment section, but the resultant cavity extended into the overlying alluvium. The pre-event water level was predicted to be reached between the years 1993 and 2018 (Thordarson, 1987), with recent measurements indicating the level is still depressed by about $50 \mathrm{~m}$, but rising at a rate of approximately $7.8 \mathrm{~m}$ per year (Chapman et al., 1994). Though radionuclide transport from the chimney was not expected until the pre-event water level was reached (U.S. Atomic Energy Commission, 1973), logging in the postshot hole at the site has revealed horizons of water outflow which, if representative of conditions outside the chimney, suggest that transport could have been occurring since the mid 1980s (Chapman et al., 1994).

Private wells in Hot Creek Valley are generally relatively shallow and thus believed to be completed in the upper part of the alluvial section. They are used for both domestic and agricultural purposes. Some springs in the area have elevated temperatures and chemical characteristics that indicate they could be discharge points for deeper, regional flow systems. The perennial yield of Hot Creek Valley is estimated to be 5500 acre-feet (Rush and Everett, 1966).

\section{DATÁ}

The specific conceptual model evaluated in this exposure assessment is that of groundwater flow transporting tritium from the Faultless test through alluvium and tuffaceous sediments to hypothetical receptor locations downgradient. By virtue of describing the solute flux through the Lagrangian concept of motion (following a particle on the Darcy scale), the analytical solution is actually independent of the transport medium, relying simply on the assigned transport properties. The only assumption required is that the particle trajectory not deviate significantly from the mean flow direction. This assumption is imbedded in the first-order approximation used to derive the 
arrival time moments of the moving plume (see Dagan et al., 1992). The method allows for matrix diffusion and sorption, but in the absence of evidence that either process is significant, they are not included in these calculations. The solute flux crossing a control plane at a given distance is calculated, and in all cases it was assumed that a receptor was located on that plane. The receptors are assumed to be single wells providing domestic supply, similar to current rural use in the area. The parameters used for the transport calculations are discussed in detail below. In some cases, lack of data requires that significant assumptions be made regarding the appropriate input values. Parametric uncertainty in all of the hydraulic properties is included through uncertainty in the estimate of the mean velocity.

\section{Source Term}

The tritium source term for the Faultless event is assumed to be $4.3 \times 10^{18} \mathrm{pCi}$. No unclassified data on the source term for Faultless are available, though measurements of tritium concentration in water samples collected from the postshot hole have been published. These measurements have been combined with assumptions about volume of contaminated water (exact chimney dimensions are also classified) to derive an estimate of the mass of tritium produced by the shot. The concentration used for these calculations is the highest concentration reported for a water sample collected from UC-1-P-2SR, $9.2 \times 10^{8} \mathrm{pCi} / 1$ tritium for a sample collected on September 2, 1976 (Thordarson, 1985), when the water level in the well was $573 \mathrm{~m}$ below land surface. For comparison, the maximum concentration of tritium measured in a water sample from the Cambric nuclear test cavity on the Nevada Test Site was $9 \times 10^{9} \mathrm{pCi} / 1$ (Hoffman et al., 1977). The measured concentration was assumed to apply to all water within the chimney volume. The chimney volume was estimated using relationships based on depth of burial (Glasstone and Dolan, 1977, p. 261), which resulted in a cylinder with a diameter of $200 \mathrm{~m}$ and a height of $500 \mathrm{~m}$. The chimney porosity was estimated as 0.30 , although porosity is undoubtedly highly heterogeneous, with vitrified regions of very low porosity and cavernous regions with high porosity. However, it was assumed that these heterogeneities average out through the chimney and that the overall porosity is slightly higher than that assumed for the native alluvium, 0.25 (see section on porosity). The resulting volume of water, $4.7 \times 10^{9}$ liters, was multiplied by the maximum sample concentration given above, to give $4.3 \mathrm{x}$ $10^{18} \mathrm{pCi}$.

\section{Discharge Mixing Area}

The discharge mixing area was assumed to be the same as the calculated vertical cross-sectional area of the chimney, $100,000 \mathrm{~m}^{2}$ (described above). The discharge mixing area is the estimated cross-sectional size of the contaminant plume as it passes the control plane. It is used in conjunction with the average velocity and porosity to derive the quantity of groundwater passing the plane, and thus convert the mass flux of contaminant into the concentration value needed for the health risk calculation. It is reasonable to maintain a constant source cross-sectional area during transport because the source size is small relative to the travel path lengths considered ( 800 and $14,000 \mathrm{~m}$, discussed in a later section) and small relative to the scale of geologic heterogeneity. Transverse spreading of the plume as it moves from the shot location to the control plane is neglected, as are the processes of matrix diffusion, mass transfer, and groundwater recharge along the flow path. 
These processes are difficult to quantify and little information was available from the site, therefore they are not included in the analysis. This is considered a conservative assumption in that dilution of the tritium plume is minimized and calculated concentrations are higher.

\section{Distance to Control Plane}

The analytic method calculates the total solute flux crossing a control plane at a given distance, and in all cases it was assumed that a single domestic supply well was located on that plane. Two scenarios are considered, with a distance of $800 \mathrm{~m}$ to the control plane in the first and $14,000 \mathrm{~m}$ to the first point of use in the second (Figure 2). The first scenario considers transport to the boundary of the DOE land withdrawal at UC-1 (the Faultless emplacement hole). This withdrawal is Public Land Order No. 4338 and includes a 640-acre site apparently centered on UC-1 (U.S. Atomic Energy Commission, 1973). Groundwater flow is believed to be to the south-southeast across this area (Dinwiddie and Schroder, 1971), but given the lack of water level data, flow to the boundary is assumed to take the shortest path, directly south, with a distance of $800 \mathrm{~m}$. No supply wells currently exist in this location, so the calculated risks are for a hypothetical scenario of someone drilling a well at the land withdrawal boundary and using it for their source of drinking water.

The second scenario considers flow to the closest existing downgradient water-use point, Six Mile Well. This well is located $14 \mathrm{~km}$ south-southeast of Faultless and is reportedly used for stock watering purposes (Rush and Everett, 1966; Thordarson and Robinson, 1971). The calculated risks for this scenario are also hypothetical in that it is assumed that the well is used as a human drinking water supply, as in the first scenario.

Both of the distances are the map distances from UC-1 to the assumed receptor location, and do not take into account any vertical components of flow. Groundwater flow is considered to be primarily horizontal in the area of UC-1 (Dinwiddie and Schroder, 1971), but vertical flow, if it occurs, would effectively lengthen the flowpaths.

\section{Effective Porosity}

The effective porosity was assumed to be 0.25 . The chimney created by the Faultless event extends through tuffaceous sediments and overlying alluvium and transport could be through either or both of these units. Examination of cores, cuttings and logs from wells drilled at and near the Faultless site led Hoover (1968, page 7) to conclude that "To a great extent the tuffaceous sediments are similar in texture, fragment sizes and general appearance to the alluvium," with differences in the degree of induration and presence of thin layers of volcanics and dispersed volcanic ash in the tuffaceous sediments. The alluvium is poorly sorted and contains fragments of volcanic and carbonate rock, presumably similar to alluvium filling basins at the Nevada Test Site. The alluvium comprising fans in northern Frenchman Flat at the NTS has been studied extensively as part of site characterization activities for a radioactive waste management facility. Porosities for over 200 core samples collected from wells and boreholes at the site were generally greater than 0.30 (Reynolds Electrical and Engineering Co., 1993a and 1993b). Given that disturbance of the samples during collection may have increased their porosity, and smaller values of porosity are more conservative because they increase the mean velocity, a value of 0.25 was used for both the alluvium and 


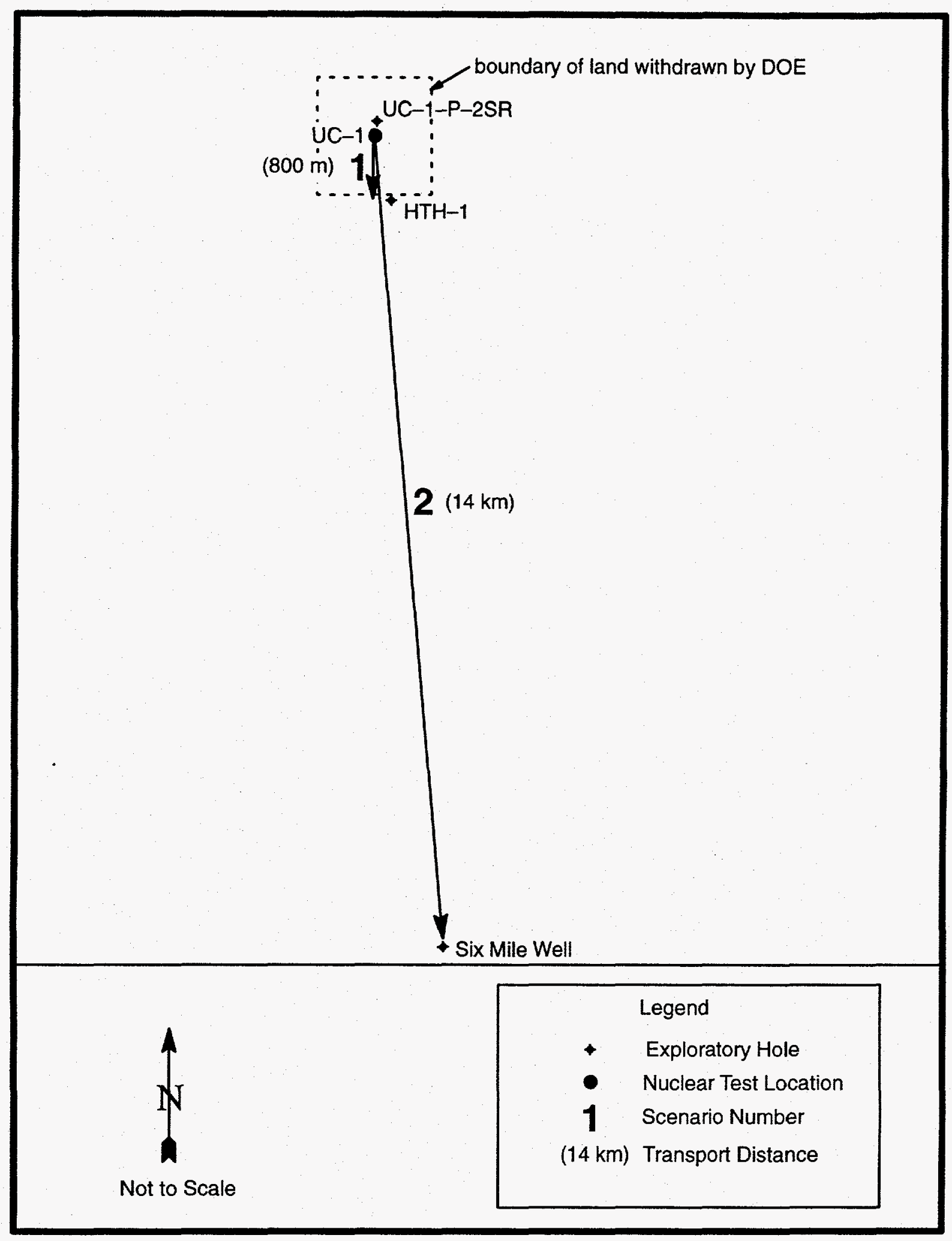

Figure 2. Diagram of the two transport scenarios considered, showing the scenario number used in the report and the transport distance used in the calculations. As described in the text, flux is calculated crossing a plane at the given distance. The diagram is not drawn to scale. 
tuffaceous sediments of Hot Creek Valley. The uncertainty in mean effective porosity is incorporated in the uncertainty in the estimate of mean velocity, discussed in a later section.

\section{Mean Groundwater Velocity}

A mean flow velocity of $42 \mathrm{~m} / \mathrm{yr}$ was used for groundwater flow to the site boundary, and a value of $2.8 \mathrm{~m} / \mathrm{yr}$ was used for flow to Six Mile Well. In the absence of direct measurements of flow velocities, the velocities were calculated, as described below.

\section{Mean Groundwater Velocity to the Site Boundary}

The mean velocity calculated for flow to the site boundary, $42 \mathrm{~m} / \mathrm{yr}$, results from a hydraulic conductivity of $1.1 \times 10^{-5} \mathrm{~m} / \mathrm{s}$, a hydraulic gradient of 0.03 , and an effective porosity of 0.25 . The choice of porosity is discussed in an earlier section. Hydraulic conductivity data for the alluvium at Faultless are available from packer tests conducted at well HTH-1 (just south of the site boundary) and other wells in adjacent valleys, and from a pumping test conducted in the alluvium at well HTH-1 with adjacent well HTH-2 used as an observation well (Dinwiddie and Schroder, 1971). The pumping test results are considered to be more representative of groundwater flow conditions at the scale of this study and so were used for the estimates of hydraulic conductivity. Depending on the effective thickness used, the test gave a range of hydraulic conductivity of $6.5 \times 10^{-6}$ to $1.1 \times 10^{-5}$ $\mathrm{m} / \mathrm{s}$. The value used in the calculations is the higher of these two endmembers, and represents the most permeable beds penetrated at the site. Transport is most likely to occur within these more conductive beds. The hydraulic gradient is calculated from well UCE-17, north of the site, to HTH-1 (based on head data from Dinwiddie and Schroder, 1971) and is consistent with estimates of pre-event hydraulic head at UC-1 (Thordarson, 1987). Dinwiddie and Schroder (1971) report a range of groundwater velocity in the HTH-1 area of 40 to $70 \mathrm{~m} / \mathrm{yr}$, using a gradient of 0.04 , effective porosity of 0.2 , and the range in hydraulic conductivity given above. It is assumed that the receptor is served by a single domestic supply well that causes no discernible impact on the gradient. Scenarios involving large production wells would require assuming steeper gradients. Uncertainties in the mean hydraulic conductivity and mean hydraulic gradient are incorporated in the uncertainty in the estimate of mean velocity.

\section{Mean Groundwater Velocity to the Six Mile Well}

The mean velocity calculated to Six Mile Well is $2.8 \mathrm{~m} / \mathrm{yr}$. The hydraulic conductivity and porosity are identical to the previous scenario, but the hydraulic gradient is lower between the site and Six Mile Well. The gradient used, 0.002 , is based on the head at HTH-1 and reports of the water level in the Six Mile Well (Rush and Everett, 1966). The difference between the on-site and regional gradients is consistent with the topography of Hot Creek Valley, with the Faultless site located close to the head of the valley and on the flank of the Hot Creek Range, and the Six Mile Well located in the wider, middle section of the valley. The topographic gradient across the Faultless site is approximately 0.05 , while the topographic gradient from the site to Six Mile Well is 0.007 . Again, there is assumed to be no impact on the hydraulic gradient by the receptor well and uncertainties in the mean hydraulic conductivity and mean hydraulic gradient are incorporated in the uncertainty in the estimate of mean velocity. 


\section{Spatial Variability in Hydraulic Conductivity}

Though a mean value of hydraulic conductivity $(K)$ is used to obtain the mean velocity, it is known that hydraulic conductivity varies through space due to geologic variability. The variability in $K$ creates flowpaths with both higher and lower mean velocities than those calculated using the mean $K$, and results in spreading of a contaminant plume along the direction of flow. The spreading is noted at the control plane as early arrivals in advance of the bulk of the contaminant mass, and a "tail" of trailing arrivals behind the bulk of the mass. The early arrivals caused by spatial variability in hydraulic conductivity are particularly important when considering transport of a decaying solute such as tritium because the mass of contaminant decreases with time. A large variance allows more variation in $K$ about the mean value and thus results in a distribution of velocities that can include much faster flowpaths than the mean. A lower variance restricts the spreading about the mean.

Although numerous packer tests were performed for wells in Hot Creek and adjacent valleys, two conditions precluded using the data for estimating spatial variability through a geostatistical analysis. First, the tests measured hydraulic properties at a scale much smaller than the scale of transport at Faultless. The effects of the packer injection tests probably extended only several meters beyond the borehole wall, while transport is possible over hundreds, or even thousands, of meters. Second, the packer testing included tests of beds having very low hydraulic conductivity that are unlikely to contribute to significant downgradient transport. The hydraulic conductivities of the alluvium and tuffaceous sediments reported by Dinwiddie and Schroder (1971) ranged from $1.6 \mathrm{x}$ $10^{-10} \mathrm{~m} / \mathrm{s}$ to $4.6 \times 10^{-6} \mathrm{~m} / \mathrm{s}$. Including this wide range of values would bias the spatial variability toward values higher than would be expected for the alluvium and tuffaceous sediments at Faultless.

The values of $\ln K$ variance used in the calculations are based on the literature. Hoeksema and Kitanidis (1985) report a median value of correlated variance for log-transformed $K$ in unconsolidated aquifers of 0.6 . Hoeksema and Kitanidis recommend using the median value because extreme cases tend to skew the mean away from the typical value. The value of 0.6 was used as the minimum for both scenarios, and the sensitivity of the calculations to $\ln K$ variance was examined using values two and four times (1.2 and 2.4, respectively) the estimated median value.

\section{Spatial Correlation Scale}

The spatial correlation scale (also known as the integral scale) is the distance over which two measurements of hydraulic conductivity tend to become uncorrelated. A large value suggests a system with a high degree of spatial correlation and has the net effect of extending the path length of higher conductivity conduits. The correlation scale of hydraulic conductivity could not be estimated from the available data at Faultless because the hydraulic test locations were too widely-spaced for the scale of transport. Analysis of correlation and overall scales for a number of well-characterized sites revealed a predictable relationship of the correlation scales being approximately ten percent of the overall scale (Figure 3) (Gelhar, 1993, p. 293). This relationship was applied to the Faultless transport scenarios so that the correlation scale used was $1 / 10$ of the flowpath length, resulting in a value of $80 \mathrm{~m}$ for the first scenario and $1,400 \mathrm{~m}$ for the second. 


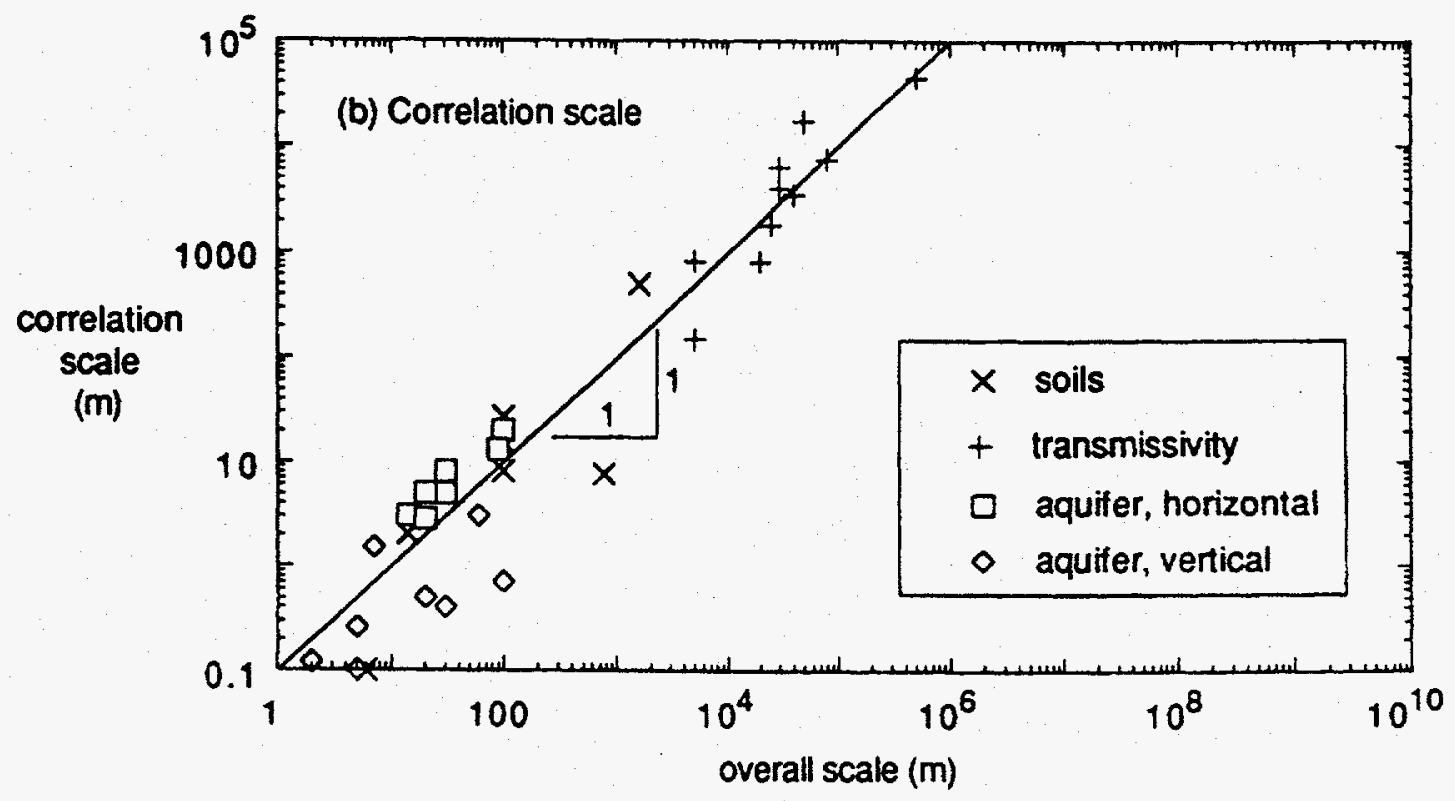

Figure 3. Correlation scales of hydraulic conductivity or transmissivity versus overall scale, as presented by Gelhar (1993). The excellent relationship is the basis for assigning a correlation scale of 10 percent to the flowpath length in this report.

\section{Estimation Error in Mean Velocity}

The estimation error in mean velocity accounts for uncertainty in the assigned mean velocity value due to uncertainties in mean effective porosity, mean hydraulic conductivity, and mean hydraulic gradient. The lack of data did not allow calculation of these uncertainties at the Faultless site. Instead, three values were assigned for the uncertainty in the estimate of mean velocity: zero, 20 , and 40 percent of the mean velocity. The estimation error of zero represents the hypothetical case where there is no uncertainty in the estimate of mean velocity. The estimation error values of 20 and 40 percent are arbitrary values chosen out of convenience to study the sensitivity of the results to a range in estimation error. The estimation error represents one standard deviation in the distribution of error about the estimated mean velocity. If we assume the error is normally distributed, then the mean value \pm two standard deviations incorporates 95 percent of the distribution. To illustrate, an estimation error of 40 percent of the mean velocity of $2.8 \mathrm{~m} / \mathrm{yr}$ (Scenario 2) corresponds to a standard deviation of $1.1 \mathrm{~m} / \mathrm{yr}$. The range of estimation error represented by the mean \pm two standard deviations is then 0.6 to $5.0 \mathrm{~m} / \mathrm{yr}$. It is important to stress that this is uncertainty in the mean velocity. 
The range of velocities in the flow field is incorporated through the spatial variability in hydraulic conductivity and would be expected to be much larger than the range of the mean.

The estimation error in mean velocity, like variance in $\ln K$, results in spreading of the contaminant plume in the direction of flow, and for the same reason: consideration of both slower and faster travel times distributed about the mean. Unlike the $\ln K$ variance, this distribution of velocities is not a result of natural geologic heterogeneity; rather it is a result of our imperfect knowledge of the natural system. Even in a well-characterized aquifer, uncertainty remains about the groundwater velocity field because data must be extrapolated from one well to another. This uncertainty can be estimated from the non-correlated variability in velocity (which is usually primarily a result of uncertainty in hydraulic conductivity). In the case of Faultless, the lack of data creates a situation of great uncertainty about the mean velocity and not enough data to estimate that uncertainty. This was handled by evaluating the importance of uncertainty through a sensitivity analysis that included zero, 20 and 40 percent. Both the variance in hydraulic conductivity and uncertainty in velocity can be determined by field measurements and the uncertainty can be reduced during that process.

\section{Tritium Half-Life}

A half-life of 12.4 years was used for the decay rate of tritium in the calculations. The decay behavior is important to the resultant solute flux because that portion of the mass traveling at slower velocities is removed by decay before reaching the control plane. This results in the elimination of long travel times from the risk calculation and a comparative emphasis on the portion of the mass subject to early arrival.

\section{RESULTS}

The shorter pathlength and higher velocity of Scenario 1 (to the DOE land boundary) results in the earliest arrival and highest peak concentration of tritium on the breakthrough curves of the two scenarios considered (Figure 4). The very short travel times calculated for Scenario 1 minimize the amount of spreading caused by spatial variability and uncertainty, as evidenced by the steep and narrow shape of the curves. The very short travel times also reduce the effect of incorporating increased uncertainty in the estimate of the mean velocity and increased spatial variability in $K$. Using the minimum values of these parameters $\left(\sigma^{2} \ln K\right.$ of 0.6 and no uncertainty in the estimate of mean velocity), the peak concentration of $1.23 \times 10^{8} \mathrm{pCi} / 1$ reaches the southern boundary 15 years after the nuclear test. Using the highest assumed values of spatial variability $\left(\sigma^{2} \operatorname{lnK}=2.4\right)$ and uncertainty ( 40 percent), the peak concentration is $1.24 \times 10^{8} \mathrm{pCi} / 1$ and reaches the boundary at 8 years.

It has been assumed that contaminated groundwater cannot migrate from the nuclear chimney until the chimney has filled and groundwater approaches the pre-event level (U.S. AEC, 1973, p. 2-5). Measurements in the post-shot hole (Chapman et al., 1994) suggest that outflow could occur before the pre-event water level is reached; but, based on the time when the chimney water level reached the suspected outflow zone, it seems most likely that migration would not occur for about 


\section{(4a)}

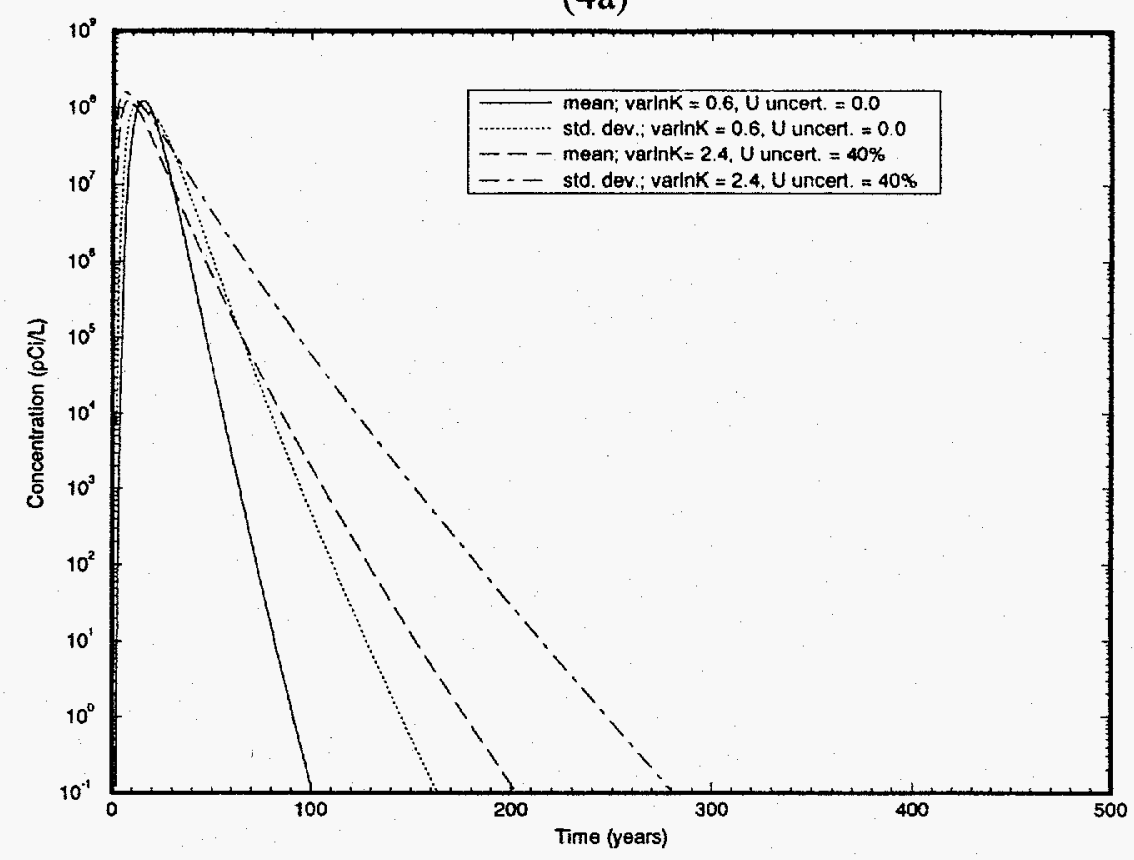

(4b)

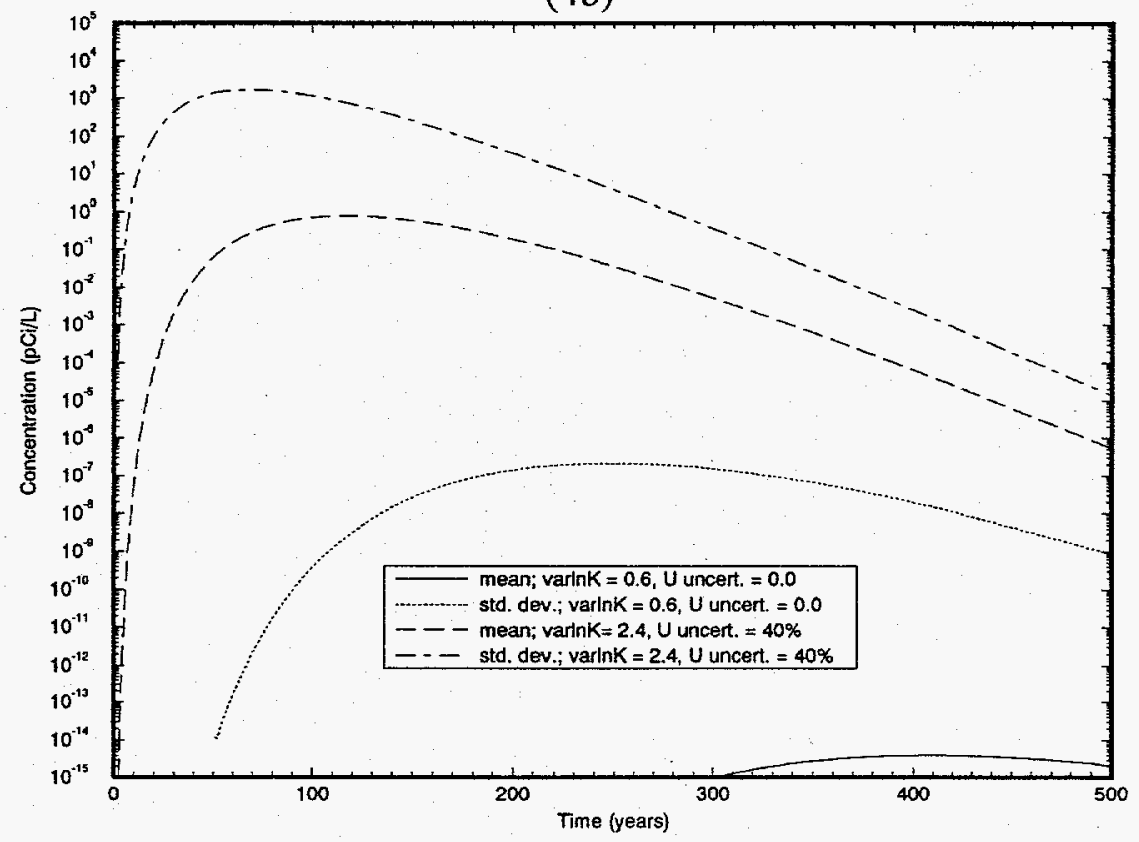

Figure 4. Tritium breakthrough curves and corresponding standard deviations for Scenario 1 (4a) and Scenario 2 (4b). The two bounding cases for each scenario are shown: the case of $\sigma^{2} \ln K=0.6$ with no uncertainty in the mean velocity estimate (Scenarios $1 \mathrm{a}$ and $2 \mathrm{a}$ on Table 1), and the case of $\sigma^{2} \ln K=2.4$ with $40 \%$ uncertainty in the mean velocity estimate (Scenarios 1f and $2 \mathrm{f}$ on Table 1). The earliest breakthrough and highest concentration occurs with Scenario 1, while Scenario 2 has the latest breakthrough and lowest concentration. 
15 years after the test. The near-field environment around nuclear tests is poorly understood and processes such as prompt injection can place nuclides in a position to migrate beyond any zone of temporary low hydraulic head. Thus, no delay in migration was considered in these calculations. If the bulk of the tritium mass is retained in the chimney prior to release, concentrations and resultant risks will be lower as a result of radioactive decay during the intervening period.

Individual adjustment of the values of spatial variability and uncertainty in the Scenario 1 calculations show that the results are relatively insensitive to the ranges used for these parameters (Figure 5). This results from the short transport travel times represented in this scenario, which do not provide an opportunity for significant spreading along the flowpath. As shown for both cases, increasing the values resulted in slightly earlier peak arrival times. The progressively longer tails of the breakthrough curves result from the longer travel times caused by incorporating greater spatial variability and uncertainty.

In Scenario 2, the combination of the much longer distance to the control plane (Six Mile Well) and the much lower mean velocity results in longer travel times, more plume spreading, and peak concentrations that are below analytical detection levels (Figure 4b). Using the minimum values of spatial variability in $K$ and uncertainty in mean velocity $\left(\sigma^{2} \ln K\right.$ of 0.6 and no uncertainty in the estimate of mean velocity), the peak concentration of $4.1 \times 10^{-15} \mathrm{pCi} / 1$ reaches Six Mile Well 410 years after the nuclear test. Using the highest assumed values of spatial variability $\left(\sigma^{2} \ln K=2.4\right)$ and uncertainty (40 percent), the peak concentration is $0.8 \mathrm{pCi} / 1$ and reaches the well at 117 years. Because the travel times are much longer than in Scenario 1, the Scenario 2 calculations are much more sensitive to the values of spatial variability and uncertainty (Figure 6). However, adjustment of these parameters to the largest values considered here did not result in detectable tritium concentrations at Six Mile Well.

The human health risks associated with Scenario 1 are above the regulatory goal of risk less than $10^{-6}$ (Table 1). The 90 percent risk confidence interval is picked between the five and 95 percent risk levels on the cumulative risk function (Figure 7). The 90 percent excess-cancer-mortality-risk confidence intervals for all cases of Scenario 1 are above the $10^{-6}$ goal for excess risk from exposure to contaminants in environmental media established by the EPA (1990). The health risk values do not vary significantly when values of spatial variability and uncertainty are adjusted because the concentration breakthrough curves were relatively insensitive to these parameters.

In contrast to Scenario 1, the health risks associated with Scenario 2 are well below regulatory goals (Table 1). The 90 percent excess-cancer-mortality-risk confidence intervals for all cases of Scenario 2 are below the EPA health risk goal of $10^{-6}$. Adjustment of the values of spatial variability and uncertainty through reasonable ranges, although resulting in wide ranges of health risk values, do not result in exceedence of the health risk goals. 
(5a)

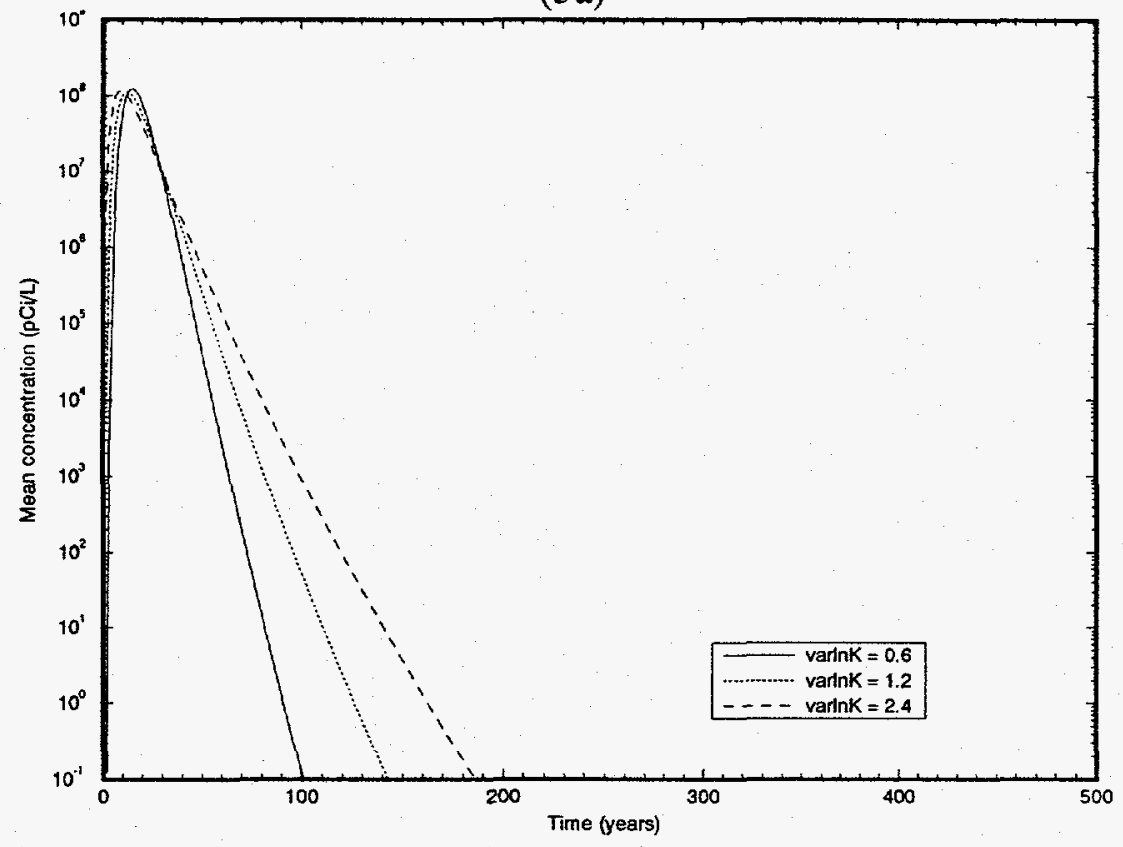

$(5 b)$

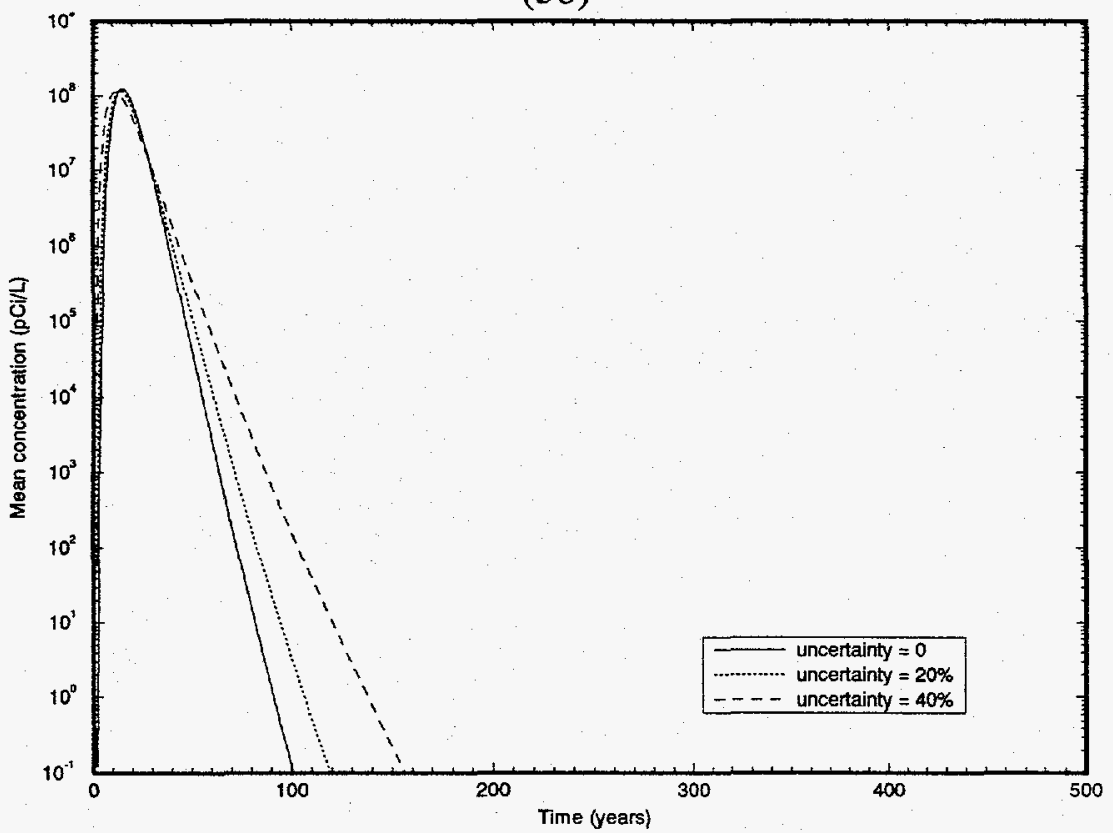

Figure 5. Sensitivity of tritium breakthrough to the value for spatial variability in $\ln K(5 \mathrm{a})$ and uncertainty in the mean velocity estimate $(5 b)$ for Scenario 1 . Increasing $\sigma^{2} \ln K$ from 0.6 to 2.4 , or increasing uncertainty from 0 to 40 percent, slightly shortens the arrival time of the peak concentration. 
(6a)

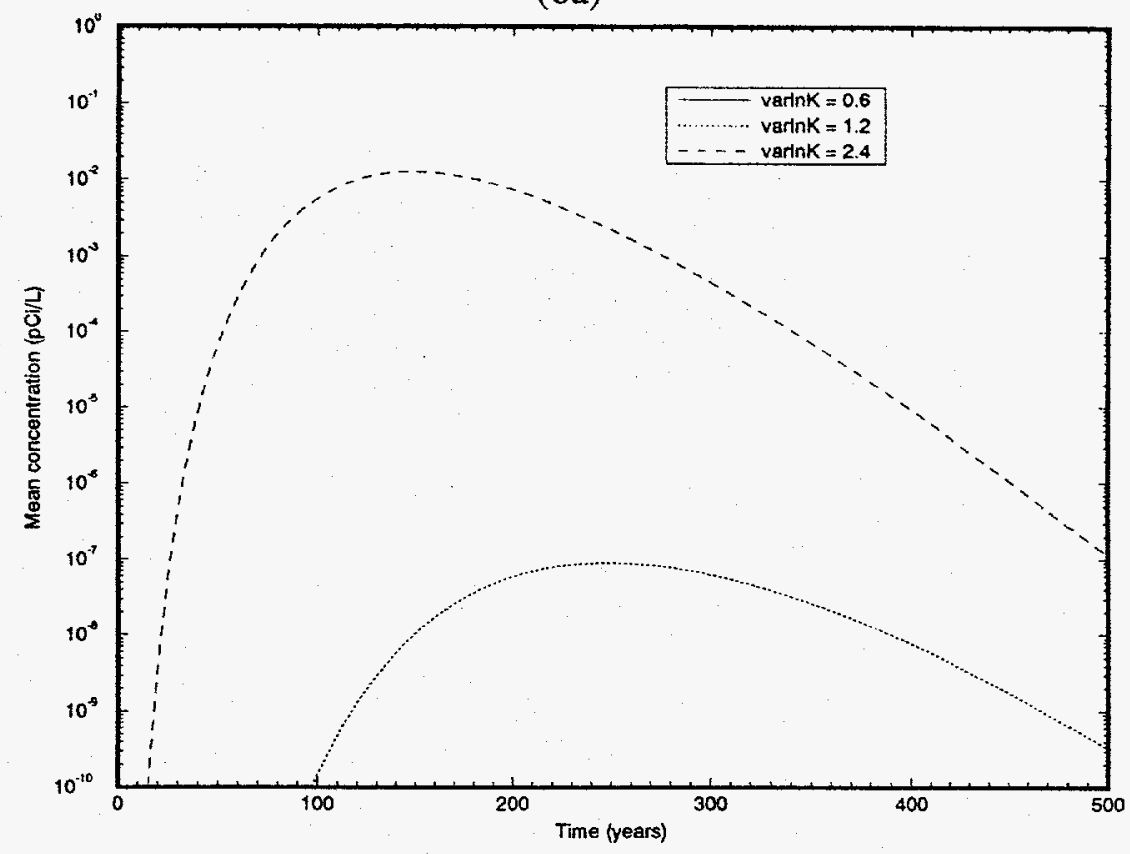

(6b)

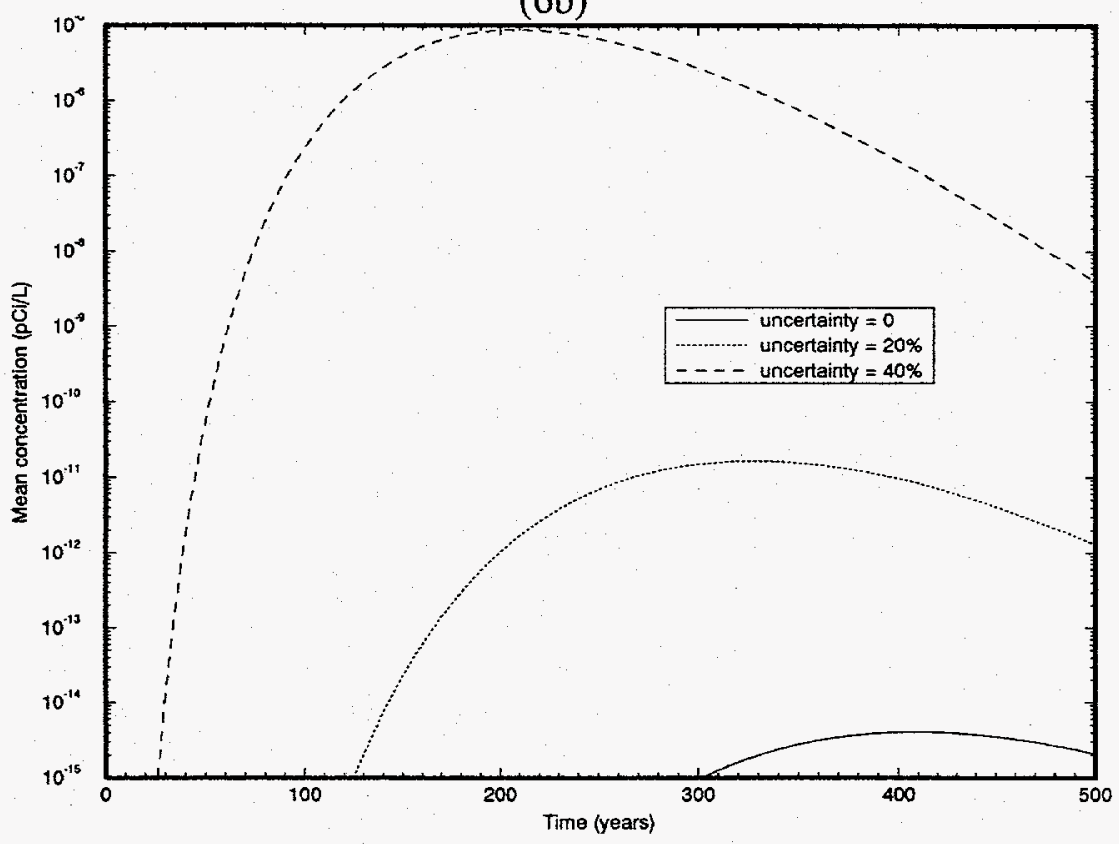

Figure 6. Sensitivity of tritium breakthrough to the value for spatial variability in $\ln K(6 \mathrm{a})$ and uncertainty in the mean velocity estimate (6b) for Scenario 2 . Increasing $\sigma^{2} \ln K$ from 0.6 to 2.4 , or increasing uncertainty from 0 to 40 percent, dramatically shortens the arrival time of the peak concentration and greatly increases the peak concentration. Note that all concentrations are below analytical detection levels. 
TABLE 1. HEALTH RISK RESULTS FOR THE GROUNDWATER TRANSPORT SCENARIOS CONSIDERED AT THE FAULTLESS SITE. The risk numbers bound the excess-cancer-mortality risk between the five and 95 percent levels on the cumulative risk function, as shown on Figure 7.

\begin{tabular}{|c|c|c|c|c|c|c|c|}
\hline Scenario & $\overline{\mathrm{U}}, \mathrm{m} / \mathrm{yr}$ & $\overline{\sigma_{0}^{2}}$ & $\sigma_{\operatorname{lnK}}^{2}$ & $\lambda$ & \multicolumn{3}{|c|}{$90 \%$ Risk Confidence Interval } \\
\hline $1 \mathrm{a}$ & 42 & 0 & 0.6 & $1 / 10 \mathrm{~L}$ & $1.4 \times 10^{-5}$ & to & $4.0 \times 10^{-3}$ \\
\hline la & 42 & $20 \%$ & 0.6 & $1 / 10 \mathrm{~L}$ & $1.8 \times 10^{-5}$ & to & $4.7 \times 10^{-3}$ \\
\hline lc & 42 & $40 \%$ & 0.6 & $1 / 10 \mathrm{~L}$ & $2.0 \times 10^{-5}$ & to & $5.4 \times 10^{-3}$ \\
\hline ld & 42 & 0 & 1.2 & $1 / 10 \mathrm{~L}$ & $2.0 \times 10^{-5}$ & to & $5.2 \times 10^{-3}$ \\
\hline le & 42 & 0 & 2.4 & $1 / 10 \mathrm{~L}$ & $1.9 \times 10^{-5}$ & to & $5.5 \times 10^{-3}$ \\
\hline if & 42 & $40 \%$ & 2.4 & $1 / 10 \mathrm{~L}$ & $1.8 \times 10^{-5}$ & to & $5.3 \times 10^{-3}$ \\
\hline $2 a$ & 2.8 & 0 & 0.6 & $1 / 10 \mathrm{~L}$ & $1.7 \times 10^{-24}$ & to & $8.8 \times 10^{-24}$ \\
\hline $2 \mathrm{~b}$ & 2.8 & $20 \%$ & 0.6 & $1 / 10 \mathrm{~L}$ & $6.8 \times 10^{-21}$ & to & $3.5 \times 10^{-20}$ \\
\hline $2 \mathrm{c}$ & 2.8 & $40 \%$ & 0.6 & $1 / 10 \mathrm{~L}$ & $1.8 \times 10^{-22}$ & to & $5.3 \times 10^{-16}$ \\
\hline $2 d$ & 2.8 & 0 & 1.2 & $1 / 10 \mathrm{~L}$ & $3.9 \times 10^{-25}$ & to & $2.6 \times 10^{-18}$ \\
\hline $2 \mathrm{e}$ & 2.8 & 0 & 2.4 & $1 / 10 \mathrm{~L}$ & $3.8 \times 10^{-18}$ & to & $2.6 \times 10^{-12}$ \\
\hline $2 f$ & 2.8 & $40 \%$ & 2.4 & $1 / 10 \mathrm{~L}$ & $1.3 \times 10^{-15}$ & to & $3.2 \times 10^{-10}$ \\
\hline
\end{tabular}

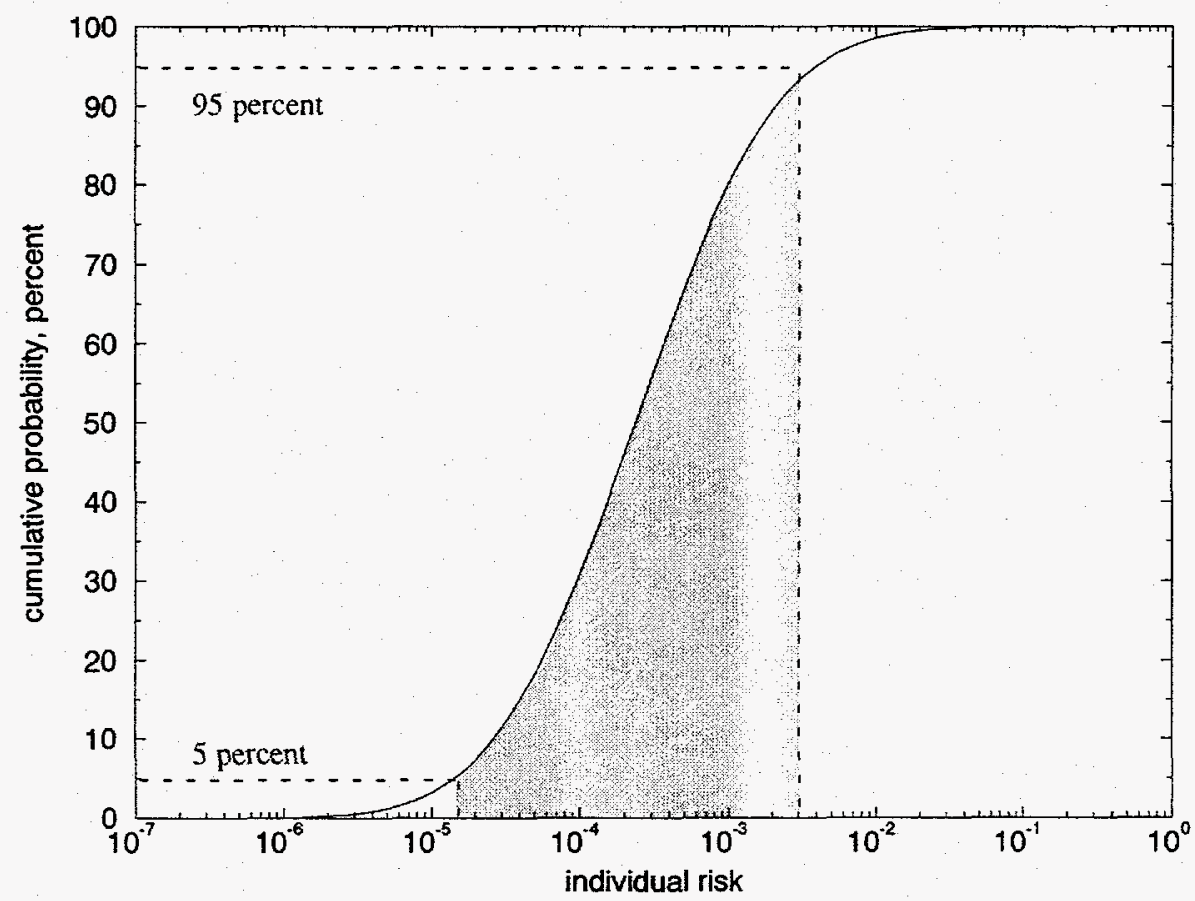

Figure 7. Probability distribution function for the excess-cancer-mortality risk calculated for Scenario 1 when the spatial variability, $\sigma^{2} \ln K$, is 0.6 , and there is no uncertainty assumed in the mean velocity estimate (Scenario 1a on Table 1). The 90 percent confidence intervals reported in Table 1 are derived from the five and 95 percent probability levels, as shown. 


\section{DISCUSSION}

Although there are uncertainties in the datasets utilized in this study, as discussed in the description of each parameter earlier in the report, these uncertainties do not have a significant effect on the risk values calculated for Scenario 1. Risk values are inherently high at the southern boundary of the DOE land withdrawal owing to the short groundwater transport pathway and the high estimated mean groundwater velocity. Uncertainty in the mean velocity and the spatial variation of hydraulic conductivity, although important to the results in terms of downgradient spreading of the tritium plume, did not have a significant impact on the calculated risk values. Therefore, further investigation of these values (through the collection of additional field data, for example) would probably not result in greatly improved estimates of risk. It is worth noting that water samples are collected annually from a well (HTH-1, Figure 2) located just beyond the land boundary and analyzed for tritium as part of the Long-Term Hydrologic Monitoring Program (U.S. EPA, 1992). Though no tritium has been detected at this well as part of that program, this does not invalidate the calculations presented here for the following reasons: 1) the completion of this well is such that it currently samples water from the deeper volcanic units and the mound created by the higher head in the volcanics may serve to deflect flow in the alluvium away from the well, and 2) the well may not be on a direct flowpath, particularly in light of a large hydraulic mound detected at an abandoned postshot hole between UC-1 and HTH-1 (Chapman et al., 1994). A detection of low-level tritium $(214 \mathrm{pCi} / 1)$ at $\mathrm{HTH}-1$ during non-routine sampling has not been confirmed by subsequent samples (Chapman et al., 1994).

At Six Mile Well, the longer groundwater pathway and the lower mean velocity lead to very low risk values. The results from this scenario are sensitive to the uncertainty in the mean velocity and the spatial variation of hydraulic conductivity, though the risk values are all orders of magnitude below the health risk goals. The large variation in risk values is directly a result of the range of values considered for spatial variability in the hydraulic conductivity field and uncertainty in mean velocity. Both of these parameters can be determined from field measurements so that the range of each could be significantly reduced with additional site data. The value of uncertainty in mean velocity can actually be reduced, and theoretically eliminated, as more velocity data are developed, reducing calculated spreading of the tritium plume. Traditionally, uncertainty in calculated groundwater velocities results primarily from uncertainty in the value of hydraulic conductivity because hydraulic conductivity usually ranges over more orders of magnitude than plausible values of either the hydraulic gradient or effective porosity. Spatial variability in hydraulic conductivity is based on geologic heterogeneity, and as such cannot be eliminated nor necessarily reduced with new data, but determining a value based on site data rather than values reported in the literature will reduce the range in risk that results from the factor of four variation considered in our calculations (0.6 to 2.4). Samples are also collected at Six Mile Well for the Long-Term Hydrologic Monitoring Program and no tritium has been found above the detection limit (U.S. EPA, 1992).

Though not addressed through sensitivity analysis, there are additional factors important to interpreting the health risks from hydrologic transport at Faultless. These are the correlation scale, discharge mixing area, and source term. As site hydrologic data are acquired to address the velocity 
uncertainty and spatial variability, data will also be available to calculate the correlation scale for the site. Though the approach taken in this work of using 0.1 of the domain is well supported by existing literature (Gelhar, 1993), the calculations are sensitive to this parameter and a value based on site data is needed. The discharge mixing area is another critical factor for the health risk calculation because it is used to convert the mass of contaminant to the concentration used as an input dose. Using the size of the test cavity is conservative, but the true size of the Faultless cavity is currently classified. Data on the true cavity size will directly affect the calculated concentrations; decreasing the concentrations if the cavity is larger than assumed, increasing them if the cavity is smaller. Furthermore, the calculation of the tritium source term required a number of assumptions, the uncertainty of which could be eliminated if calculations of the tritium produced by the test are declassified. Finally, other radionuclides were produced by the test and may need to be considered.

\section{CONCLUSIONS}

This exposure assessment provides a range of possible human health risk at two locations due to groundwater transport from the Faultless underground nuclear test. These locations correspond to the boundary of the land under DOE control (where no wells currently exist) and the closest existing well (Six Mile Well). The range in excess risk is within the EPA goal for excess risk due to environmental contaminants $\left(10^{-6}\right)$ at Six Mile Well. Calculations considering high spatial variability in hydraulic properties and/or high uncertainty in the mean groundwater velocity are also within the EPA goal. At the DOE boundary, the range in excess risk exceeds the EPA goal, regardless of the values of spatial variability and uncertainty. The range in values of excess risk can be reduced with additional field data from the site; however, incorporation of additional data, which would likely be obtained at great expense, is unlikely to result in significant refinement of the results.

\section{REFERENCES}

Andricevic, R. and V. Cvetkovic, 1995, in review, Evaluation of risk from contaminants migrating by groundwater. Submitted to Water Resources Research.

Andricevic, R., J.I. Daniels and R.L. Jacobson, 1994, Radionuclide migration using a travel time transport approach and its application in risk analysis. Journal of Hydrology, V. 163, pp.125-145.

Chapman, J.B., T.M Mihevc and B.F. Lyles, 1994, The Application of Borehole Logging to Characterize the Hydrogeology of the Faultless Site, Central Nevada Test Area. Desert Research Institute, Water Resources Center Publication \#45119, DOE/NV/10845-35, 36 p.

Dagan, G., V. Cvetkovic, and A. Shapiro, 1992, A solute flux approach to transport in heterogeneous formations 1. The general approach. Water Resources Research, V. 28, No. 5, pp. 1369-1376.

Daniels, J.I., R. Andricevic, L.R. Anspaugh and R.L. Jacobson, 1993, Risk-based screening analysis of ground water contaminated by radionuclides introduced at the Nevada Test Site (NTS), Lawrence Livermore National Laboratory Report, UCRL-ID-112789.

Dinwiddie, G.A. and L.J. Schroder, 1971, Summary of Hydraulic Testing in and Chemical Analysis of Water Samples from Deep Exploratory Holes in Little Fish Lake, Monitor, Hot Creek, and Little Smoky Valleys, Nevada. U.S. Geological Survey Report USGS-474-90, 70 p. 
Ershow, A.G. and K.P. Cantor, 1989, Total Water and Tapwater Intake in the United States: Population-Based Estimates of Quantities and Sources. Federation of American Societies for Experimental Biology, Bethesda, MD, National Cancer Institute Order \#263-MD-810264.

Fiero Jr., G.W., 1968, Regional Hydrology Hot Creek-Little Smoky Valley Flow System, Nye County, Nevada. Desert Research Institute, Water Resources Center Report \#44006, 22 p.

Freeze, R.A. and J.A. Cherry, 1979, Groundwater, Prentice-Hall, Inc., Englewood Cliffs, New Jersey, $604 \mathrm{p}$.

Gelhar, L.W., 1993, Stochastic Subsurface Hydrology. Prentice Hall, Englewood Cliffs, New Jersey, $390 \mathrm{p}$.

Glasstone, S. and P.J. Dolan, 1977, The Effects of Nuclear Weapons, 3rd Edition. U.S. Dept. of Defense and U.S. Dept. of Energy, 653 p.

Hoeksema, R.J. and P.K. Kitanidis, 1985, Analysis of Spatial Structure of Properties of Selected Aquifers. Water Resources Research, Vol. 21, pp. 563-572.

Hoffman, D.C., R. Stone and W.W. Dudley, Jr., 1977, Radioactivity in the Underground Environment of the Cambric Nuclear Explosion at the Nevada Test Site. Los Alamos Scientific Laboratory Informal Report LA-6877-MS. 89 p.

Holmes and Narver, 1974, Summary Report: Central Nevada Test Area Demobilization and Restoration Activities. Report prepared for the U.S. Atomic Energy Commission, Nevada Operations Office, NVO-152, $61 \mathrm{p}$.

Hoover, D.L., 1968, Lithologic Logs of Drill Holes in the Faultless Area, Hot Creek Valley, Nevada. U.S. Geological Survey, Technical Letter: Central Nevada 17, 12 p.

International Commission on Radiological Protection (ICRP), 1991, ICRP Publication 60: 1990 Recommendations of the International Commission on Radiological Protection. Pergamon Press, New York, NY, Vol. 21, No, 1-3.

International Commission on Radiological Protection (ICRP), 1990, ICRP Publication 56: Age-Dependent Doses to Members of the Public from Intake of Radionuclides: Part I. Pergamon Press, New York, NY, Vol. 20, No. 2.

Jain, S.C., A. Nagaratnam, A.R. Reddy, M.M. Gupta and S.C. Mehtall, 1992, Revised Age-Dependent Doses to Members of the Public from Intake of Radionuclides Using the New Tissue Weighting Factors. Radiat. Prot. Dosim., Vol. 40, pp. 111-115.

National Research Council, 1994, Science and Judgement in Risk Assessment. National Academy Press, Washington, D.C., 651 p.

National Research Council, 1990, Health Effects of Exposure to Low Levels of Ionizing Radiation, BEIR V. National Academy Press, Washington, DC. 
Rush, F.E. and D.E. Everett, 1966, Water-Resources Appraisal of Little Fish Lake, Hot Creek, and Little Smoky Valleys, Nevada. State of Nevada Department of Conservation and Natural Resources, Ground-Water Resources-Reconnaissance Series Report 38, 38 p.

Reynolds Electrical and Engineering Co., Inc., Special Projects Section, 1993a, Hydrogeologic Data for Science Trench Boreholes at the Area 5 Radioactive Waste Management Site, Nevada Test Site, Nevada. Report prepared for the U.S. Dept. of Energy, Nevada Operations Office, variable paging.

Reynolds Electrical and Engineering Co., Inc., Special Projects Section, 1993b, Site Characterization and Monitoring Data From Area 5 Pilot Wells, Nevada Test Site, Nevada. Report prepared for the U.S. Dept. of Energy, Nevada Operations Office, variable paging.

Thordarson, W., 1987, Hydrogeology of the Faultless Site, Nye County, Nevada. U.S. Geological Survey, Water-Resources Investigations Report 86-4342, 40 p.

Thordarson, W., 1985, Hydrogeologic Monitoring at the Faultless Site, Nye County, Nevada. U.S. Geological Survey Open-File Report 84-580, 37 p.

Thordarson, W. and B.P. Robinson, 1971, Wells and Springs in California and Nevada Within 100 Miles of the Point $37^{\circ} 15^{\prime}$ N., $116^{\circ} 25^{\prime}$. W., on the Nevada Test Site. U.S Geological Survey Report USGS-474-85, 178 p.

U.S. Atomic Energy Commission, 1973, Planning Directive - Demobilization, Restoration and Monitoring, Central Nevada Test Area. U.S. Atomic Energy Commission, Nevada Operations Office, NVO-90, 5 p. + appendices.

U.S. Environmental Protection Agency, 1992, Offsite Environmental Monitoring Report: Radiation Monitoring Around United States Nuclear Test Areas, Calendar Year 1991. EPA 600/R-93/141, $232 \mathrm{p}$.

U.S. Environmental Protection Agency, 1990, National Oil and Hazardous Substances Pollution Contingency Plan, Final Rule (40 CFR Part 300). Federal Register V. 55, No. 46, pp. 8666-8865. 


\section{DISTRIBUTION}

Desert Research Institute

Roger Jacobson

Desert Research Institute

Water Resources Center

P.O. Box 19040

Las Vegas, NV 89132-0040

Marjory Jones

Desert Research Institute

Water Resources Center

P.O. Box 60220

Reno, NV 89506-0220

\section{International Technology Corp.}

Richard M. Deshler

International Technology Corporation

$4330 \mathrm{~S}$. Valley View

Suite 114

Las Vegas, NV 89103-4047

Rick Waddell

Geotrans, c/o IT

4330 Valley View

Suite 112, MS-439

Las Vegas, NV 89103-4047

Joe Yeasted

International Technology Corporation

$4330 \mathrm{~S}$. Valley View

Suite 114

Las Vegas, NV 89103-4047

\section{Lawrence Livermore National Laboratory}

Lee Davisson

Nuclear Chemistry Division

Lawrence Livermore National Laboratory

P.O. Box 808

L-237

Livermore, CA 94550
Greg Nimz

Lawrence Livermore National Laboratory

P.O. Box 808

MS L233

Livermore, CA 94550

Los Alamos National Laboratory

Joe Thompson

Los Alamos National Laboratory

INC-11, MS J514

P.O. Box 1663

Los Alamos, NM 87545

Raytheon Services Nevada

Stuart E. Rawlinson

Raytheon Services Nevada

P.O. Box 95487, M/S 580

Las Vegas, NV 89193-5487

Reynolds Electrical \& Engineering Co.

Martha DeMarre

Chief, Document Research Section

Health Protection Dept.

Reynolds Electrical \& Engineering Co.

P.O. Box 98521

Las Vegas, NV 89193-8521

Brian Dozier

Reynolds Electrical \& Engineering Co.

2501 Wyandotte

Mercury, NV 89102

\section{Sandia National Laboratories}

David Gallegos

Sandia National Laboratories

Department 6331

P.O. Box 58.., M/S 1345

Albuquerque, NM 87185-1345

\section{State of Nevada}

Larry Franks

Nevada State Health Department

Radiological Health Section

620 Belrose Avenue

Las Vegas, NV 89158 


\section{U.S. Department of Defense}

David Bedsun

Defense Nuclear Agency

Field Command

Nevada Operations Office

P.O. Box 208

Mercury, NV 89023-0208

\section{U.S. Department of Energy}

Gylan Allen, Director

Test Operations Division

Nevada Operations Office

U.S. Department of Energy

P.O. Box 98518

Las Vegas, NV 89193-8518

Joanne M. Bradbery, Director

Contracts Division

Nevada Operations Office

U.S. Department of Energy

P.O. Box 98518

Las Vegas, NV 89193-8518

Kevin Cabble

Environmental Restoration Division

Nevada Operations Office

U.S. Department of Energy

P.O. Box 98518

Las Vegas, NV 89193-8518

Doug Duncan

Hydrology Program Manager

Office of Environmental Restoration and Waste Management

Nevada Operations Office

U.S. Department of Energy

P.O. Box 98518

Las Vegas, NV 89193-8518

Donald Elle, Director

Environmental Protection Division

Nevada Operations Office

U.S. Department of Energy

P.O. Box 98518

Las Vegas, NV 89193-8518
Joseph N. Fiore, Acting Assistant Manager

Office of Environmental Restoration

and Waste Management

Nevada Operations Office

U.S. Department of Energy

P.O. Box 98518

Las Vegas, NV 89193-8518

Joseph H. Kitchen

Project Control and Technology

Development Division

Nevada Operations Office

U.S. Department of Energy

P.O. Box 98518

Las Vegas, NV 89193-8518

Steve Lawrence

Environmental Restoration Division

Nevada Operations Office

U.S. Department of Energy

P.O. Box 98518

Las Vegas, NV 89193-8518

John S. Ledbetter

Contracts Division

Nevada Operations Office

U.S. Department of Energy

P.O. Box 98518, MS 505

Las Vegas, NV 89193-8518

Kevin Leary

Environmental Restoration Division

Nevada Operations Office

U.S. Department of Energy

P.O. Box 98518

Las Vegas, NV 89193-8518

Steve Leedom

Test Operations Division

Nevada Operations Office

U.S. Department of Energy

P.O. Box 98518

Las Vegas, NV 89193-8518

Steve Mellington, Director

Environmental Restoration Division

Nevada Operations Office

U.S. Department of Energy

P.O. Box 98518

Las Vegas, NV 89193-8518 
Richard Pearl

Environmental Protection Division

Nevada Operations Office

U.S. Department of Energy

P.O. Box 98518

Las Vegas, NV 89193-8518

David S. Shafer

NV/Albuquerque Laboratories Division

Office of Southwestern Area Programs

U.S. Department of Energy

EM-452, Trevion II Bldg.

1000 Independence Ave., SW

Washington, D.C. 20585

\section{U.S. Environmental Protection Agency}

Deb Shaloud

Environmental Monitoring Systems Laboratory

Office of Radiation Protection

U.S. Environmental Protection Agency

P.O. Box 93478

Las Vegas, NV 89193-3478

\section{U.S. Geological Survey}

Virginia Glanzman

U.S. Geological Survey

Box 2506, MS 913

Denver Federal Center

Denver, CO 80225

Randy Laczniak

U.S. Geological Survey

Water Resources Division

6770 S. Paradise Rd.

Las Vegas, NV 89119

Paul Orkild

U.S. Geological Survey

Box 2506, MS 913

Denver Federal Center

Denver, CO 80225

Doug Trudeau

U.S. Geological Survey

Water Resources Division

6770 S. Paradise Rd.

Las Vegas, NV 89119

\section{LIBRARIES}

Annie Kelley

State Documents Department

Nevada State Library

Capitol Complex

Carson City, NV 89710

Archives

Getchell Library

University of Nevada, Reno

Beverly Carter

MacKay School of Mines Library

University of Nevada, Reno

Document Section, Library

University of Nevada, Las Vegas

4505 Maryland Parkway

Las Vegas, NV 89154

Library (Stead)

Desert Research Institute

P.O. Box 60220

Reno, Nevada 89506-0220

Library

IT Corporation

4330 S. Valley View

Suite 114

Las Vegas, NV 89103

ATTN: Toni Miller

Library

Southern Nevada Science Center

Desert Research Institute

P.O. Box 19040

Las Vegas, NV 89132-0040

Technical Information Resource Center

Nevada Operations Office

U.S. Department of Energy

P.O. Box 98518

Las Vegas, NV 89193-8518

Librarian

Water Resources Center Archives

$4100^{\prime} B$ Brien Hall

University of California

Berkeley, CA 94720-1718 